\title{
The sacredness of reinforced concrete between structural and formal links
}

\author{
S. Bertorotta \& F. Scibilia \\ Department of Architecture, Palermo University, Italy
}

\begin{abstract}
This paper examines the design of some religious buildings built of reinforced concrete during the post-war period in the city of Palermo. After an introduction to Italy's architectural panorama, in which the principal trends in religious architecture during the period considered are set forth, marked by the appearance of reinforced concrete, Palermo's panorama will be discussed in depth, together with its specific cultural features and some creations of religious buildings in which the use of reinforced concrete becomes more mature and aware. The new technology, in fact, at first hidden behind stone claddings, was progressively unveiled through an ever more aware use of its structural and aesthetic potentials.
\end{abstract}

Specifically, out of the three structural categories identified through a systematic examination of all the religious buildings of the period, the focus will be placed on the one defined as "portal-type". These churches represent the period of "transition" to be looked at more closely better than others, with their frequent mixing of traditional techniques and the "new" reinforced concrete technology. Even if their structures cannot yet be classed as framed structures insofar as often lacking in transversal links to the portals, the roofs of these buildings, all between 20 and 30 meters and characterized by sizeable spreads without any intermediate supports, represented a field of total experimentation for the leading architects of the time.

These architects were receptive to the influences of much more daring experimentation at a national and European level. They fully absorbed said influences, interpreting them in a way that did not betray the materials and techniques of local architecture.

Keywords: reinforced concrete, structural evolution, religious architecture $X X$ century, covering large spans. 


\section{Religious architecture in Italy from the Concordat up through Vatican Council II}

To offer a summary of religious architecture in Italy over a period of some forty years lies outside the intention of these notes. Within the limits this contribution imposes the attempt will be made to set forth some design trends that developed between the thirties and the sixties, useful for inserting the projects (to be considered in what follows) into a broader-based architectural discussion.

It is known that with the signing of the Lateran Treaties in 1929, the Roman Catholic Church took on a primary role in the organization of social life once again, starting up a sizeable program of construction of church buildings in Italy, aimed at affirming its own renewed prestige. (On the church's role during the Fascist period, see [1] to which the reader is referred for a bibliography on the subject.) The increase in building construction as regards the construction of new churches starting from the thirties took place throughout the nation's entire territory.

This gave rise in a first phase to the affirmation of a conservative trend, of which the Church, always tending to perpetuate a type of architecture that is more tied to a traditionalist approach, became a proud witness. In opposition to this widespread orientation were, instead, a small number of churches that, following the example of what was taking place in other European countries Germany first of all - distinguished themselves by their search for an explicitly modern language.

Nationally, there is seen in this regard some examples of experimentation in typologies and languages that demonstrate the break with tradition. Among these may be mentioned, as examples, the chapel of the Victor Emanuel III sanatorium in Alexandria by Ignazio Gardella (1930). Its well-defined squared volume, total absence of decoration and use of a flat roof, display a definite influence of the coeval European experiences or, to cite another, the church of San Michele Arcangelo in Foggia by Concezio Petrucci (1934).

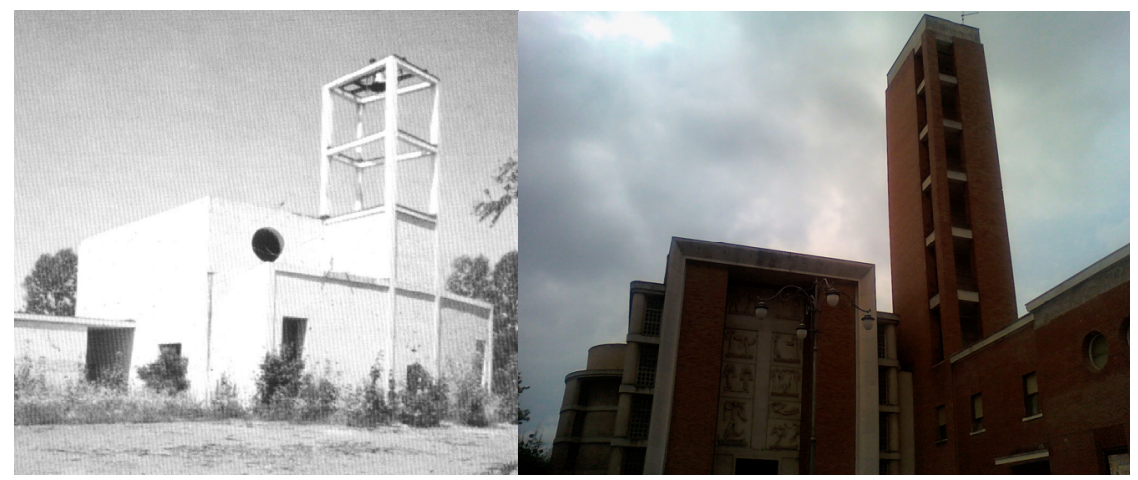

Figure 1: Chapel of the Victor Emanuel III sanatorium in Alexandria and church of San Michele Arcangelo in Foggia, exterior view. 
A reflection of this opposition between two different tendencies in the discussion on church building design is seen to be the affair tied to the nationwide competitions. If the competition regarding the $1930 \mathrm{La}$ Spezia cathedral was tied to an openly declared traditionalism, in the series of competitions for the churches to be built in the Messina diocese [2], in which openness to more innovatory solutions was also tied to the decision of Monsignor Paino, archbishop of Messina, to delegate to the Architects' National Association the formation of the call for bids for nineteen new parish churches, of which two must possess a "marked character of modernity".

The presence of projects bearing the stamp of a language of rationalist matrix, such as, among others, those of Giuseppe Samonà, Mario Ridolfi, Ernesto La Padula, Ettore Sottsass, did not however form an obstacle to the criticism of magazines like Arte Cristiana, which interprets the Church's position, whose judgement was negative on the projects presented, considering them inappropriate to expressing the image that the Church wished to transmit. There having been devoted an entire issue of Architettura, one of the period's most authoritative magazines, to the Messina call for bids, however, excited great interest among the designers of the time, showing how there could exist a sound alternative to the prevalent traditionalism in the design of church spaces.

One demonstration of the orientation supported by the Roman Catholic church for a long time was provided by the fact that the new reinforced-concrete technology, which became widely spread in Italy starting from the first decade of the $20^{\text {th }}$ century [3] - owing as well to such companies as the well-known Ing. Porcheddu Company of Turin, which introduced the Hennebique system and built important public works - at first found no significant applications for church buildings. These latter continued to privilege the use of traditional materials or the traditional use of new materials.

A fundamental pause for architecture in general and religious architecture in particular came about through the second world war (for a summary of religious architecture in Italy during the fifty years 1945-1995 [4]), since during the postwar period a substantial population increase was triggered off in the mediumsized and large cities. This gave rise to the population of peripheral urban spaces with the consequent need for new poles of worship.

Between the forties and fifties there arose a multitude of new churches that, although often tied to scant economic resources and impelling urgencies, did not fail to display a number of examples of high quality, which indicate the coexistence of various trends.

Of significance turned out to be a group of designers who, even having different styles that characterize their creations, were distinguished by the renewed dialogue with tradition that they displayed, through the reinterpretation of suggestions provided by regional architecture. Among these to be remarked are (to name only a few) Giovanni Michelucci (during his first season), Raffaello Fagnoni, Giuseppe Nicolosi, Nicola and Leonardo Mosso, and Giovanni Muzio [4].

The architecture of the churches was often characterized, especially starting from the mid-fifties, by an obvious structural daring, as is shown by the Roman 
churches of the Sacred Heart of the dying Jesus by Ildo Avetta (1953-1955), distinguished by a sequence of parabolic transepts to support the roof, and of San Gregorio VII by Giulio Paniconi and Mario Pediconi (1958-1961) having a cruciform-columns structure of varying cross section with truss beams to support the roof. (For a panoramic view of Roman churches during the 20th century see [5].)
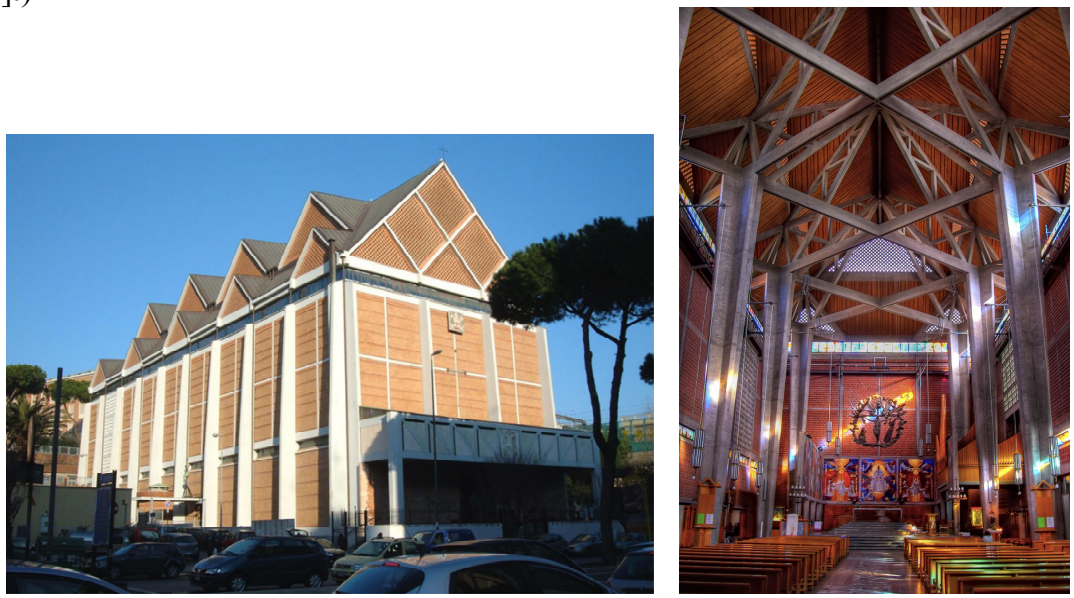

Figure 2: $\quad$ Rome, church of San Gregorio VII, exterior and interior view.

With reference to the local context, in Sicily at least deserving of mention is the sanctuary of the Madonna delle Lacrime at Syracuse, for whose competition (1956) ninety-one designs were presented, all oriented toward the monumental as required by the special assignment for the temple (conceived for large numbers of pilgrimages), among which the winner was that of Michel Andrault and Pierre Parat, built, with significant changes to the project, with an enormous spire as roof (100 $\mathrm{m}$ high and $90 \mathrm{~m}$ in diameter) and the church for Gibellina (province of Trapani), designed after the Belice earthquake in 1968 by Ludovico Quaroni and Luisa Anversa, whose emerging element is the sphere, inspired by the visionary projects of Boullé and Ledoux.

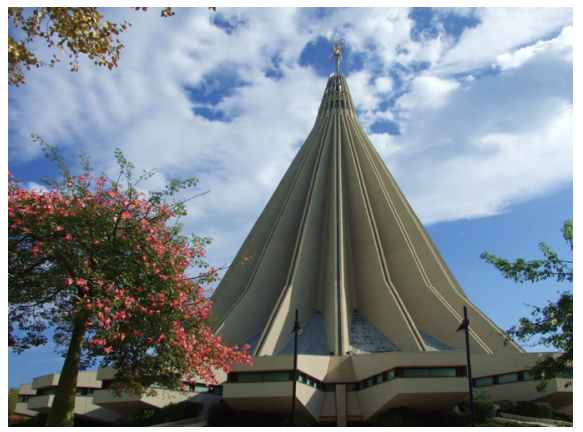

Figure 3: Syracuse, sanctuary of the Madonna delle Lacrime, exterior view. 
The process of winning freedom from historical references could be considered to be concluded and the rendering explicit of the structural design would lead, most especially starting from the sixties, to the spread of an exasperated brutalism, often tied to the use of fair-face reinforced concrete. This is shown by, for example, the Roman churches of Santa Maria della Visitazione (1969-1971) by Saverio Busiri Vici and of the Assunzione di Maria by Saverio Muratori, whose final results would not always be wholly convincing.

The liturgical reform brought about by Vatican Council II with the constitution of the Sacrosantum Concilium (1963) would mark a turning point, which would be followed by a profound rethinking of ecclesiastical space.

\section{The panorama of church architecture in Palermo during the two decades 1945-1965}

The city of Palermo saw during the twenty years successive to the war a massive and systematic work of reconstruction. This led to the birth of a series of "satellite quarters" that, in design intentions, should have been self-sufficient, constituting an evolved alternative to the traditional model of city organized around one center only.

In reality their construction brought about "dormitory districts" devoid of the most elementary services and equipping. Thus was generated a buildingconstruction and social isolation and deterioration that is still obvious even today. The only elements to provide a gleam of vitality and humanity to these installations were the churches and their annexed social facilities, often designed at the same time as the quarters were being built, in line with both the number of inhabitants and the nearness of further religious buildings.

Between 1945 and 1965 Palermo was witness to a series of religious buildings, often tied to the construction of these districts, whose design was a field of experiment for many local designers, such as Giuseppe Spatrisano, Vittorio Ziino, Pietro Ajroldi, Giuseppe Vittorio Ugo, Giuseppe Carpinteri, Pietro Scibilia and Luigi Epifanio, assisted by structural designers (Ugo Fuxa, Antonio Emanuele Rizzo, etc.). (For a summary of religious architecture in Palermo during the 19th and 20th centuries see [6].)

Aided by the general existing process of acceptance of reinforced-concrete technology, of the calculation processes tied to it and of the expressive potentials native to it, and the openness of a part of the Church to the new technology, made explicit in the Vatican II Ecumenical Council, with which there was "abandoned the posture of conflict and of polemics" by proposing a "dialogue between the church and contemporary culture" [7], the church building constituted an occasion for the designer to measure themselves against structurally daring solutions.

Time-wise the construction of the churches considered coincides with the stay in Palermo of Cardinal Ernesto Ruffini. He became promoter of the creation of a series of social services (schools, social centers, health and medical facilities, homes for the aged) among which the church was the most representative building [8]. 

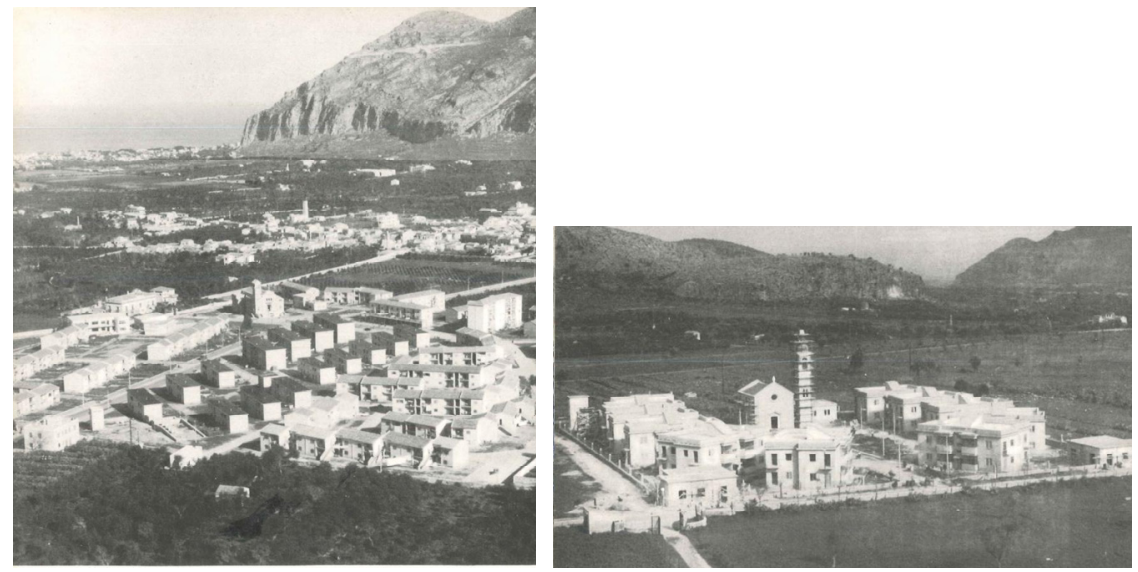

Figure 4: Historic photographs of the Ernesto Ruffini's village and of the Hospitality village (by La Chiesa oggi. Un decennio di episcopato di Sua Eminenza il cardinale Ernesto Ruffini a Palermo, 1949-1956, s.n., Palermo 1956).

The churches built in Palermo during that period numbered around thirty. Were it desired to study them synchronically it would be possible to subdivide them into three classes, which correspond to the slow process of structural and formal acceptance and maturing of reinforced-concrete technology. This process takes explicit form fundamentally in the design of the roofs, the members principally responsible for the definition of the space and, in view of the considerable spans, the true field of structural experimentation.

Some of the churches, less interesting for the purposes of this study, display a "mixed" structure, which uses reinforced concrete solely as a means of locallyused reinforcing (shelf-girders, lintels, non-framed columns), they continuing to assign to masonry the load-bearing role and to wooden trusses the support structure for the roofs. This typology does not display, furthermore, any formal innovation in the facades: simplified languages, longitudinal plans, if having aisles then outfitted with lowered side chapels and having roofs independent of the roof of the nave, an absence of transepts, wall openings of reduced size, bell towers of limited height and almost never standing alone.

A second category of buildings structurally defined as "portal types" takes advantage of the engineering and expressive potentials of in situ casts-in-place, which design chooses in only a few cases to leave fair face, without further cladding, while in others they are concealed behind claddings of various kinds.

The two attitudes are the expression of the quarrel between the critics of "liquid mud", as during the thirties Ugo Ojetti still called concrete, for whom the sole value acknowledged to the new technology was structural, not formal, and those who acknowledge expressive value to the nude material with its form marks printed on it. In these buildings the spans become more daring and the roofs become a field of structural experiment and in some cases formal experiment as well. 
As against this, few are the attempts to make legible the bearing structure and the distribution by the treatment of the façade, which remains clad and which is connoted by a prevalence of fulls over voids, something dissonant with the structural potentials of reinforced concrete.

The churches belonging to the third category described all display a more mature and aware language, often brought close to the conception of the central plan. The bearing frames are wisely brought out and the outside facades are lightened by means of large openings and sizeable porticos, which contribute to a general feeling of the prevalence of voids over fulls, a sign of the proper and sincere use of construction technique.

\subsection{The reinforced-concrete "portal-type" churches between tradition and innovation}

Among the churches belonging to this category will be briefly studied those deemed to be innovatory from the structural and architectural standpoints, for which it is necessary to underscore their structural vulnerability crosswise to the portals (also because of the constant absence of the transept). Among these examples may be noted the churches of Sant'Antonio da Padova, of San Francesco di Sales, of Santa Luisa di Merillac, of SS. Lucia Vergine e Martire and of San Paolo Apostolo.
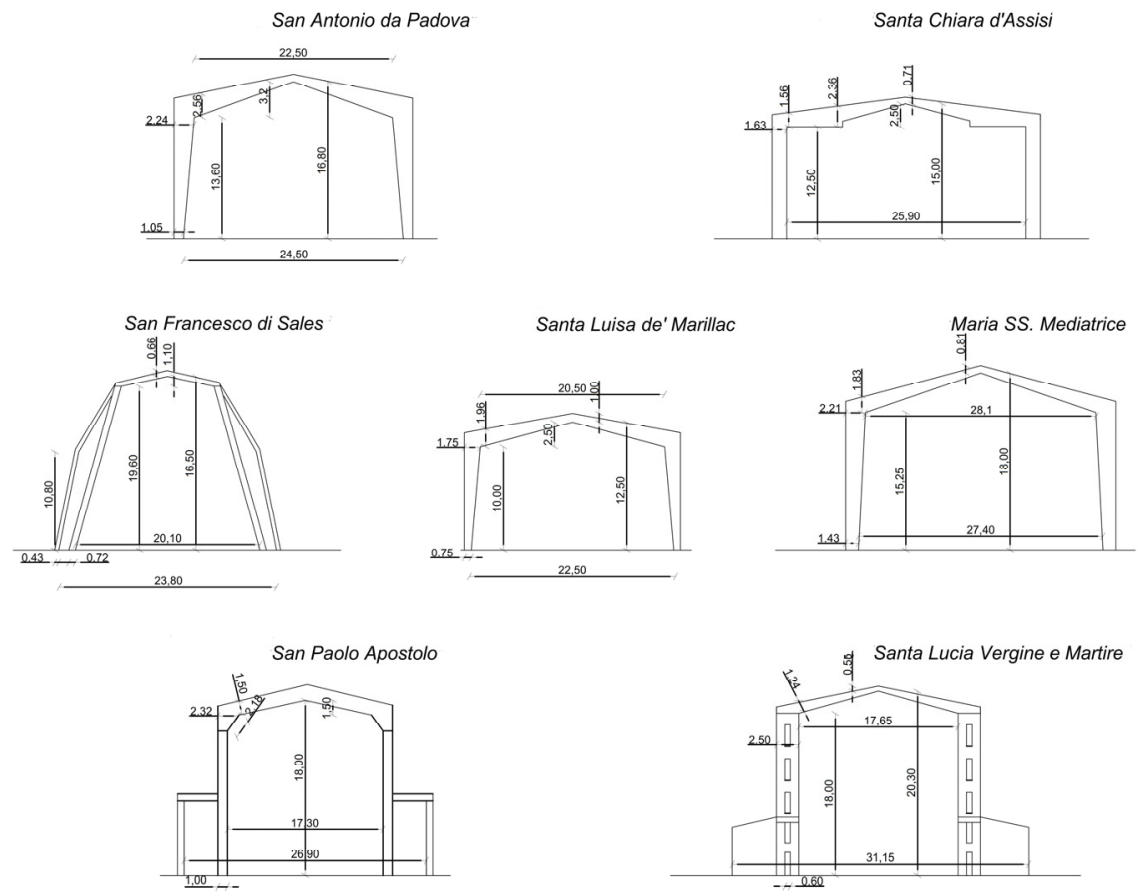

Figure 5: Structural scheme of "portal-type" churches. 
In the church of Sant'Antonio da Padova, designed by Vittorio Ziino and by Ugo Fuxa in 1954-1956, in spite of a façade having a traditional design, the roofs reinforced-concrete structure, having the considerable maximum span of 22.50 meters, achieves full expressive maturity: the five symmetric variablecross-section portals both in the piers and in the crosspieces are juxtaposed to another twenty "rampant" ones oriented mirror-image-wise in the central span and with different postures in the other spans and in the zone of the apse, to generate a complex play having a dual radial reading key starting from the vertices of the uprights or starting from the vertices located in imagination along the ridge of the roof.
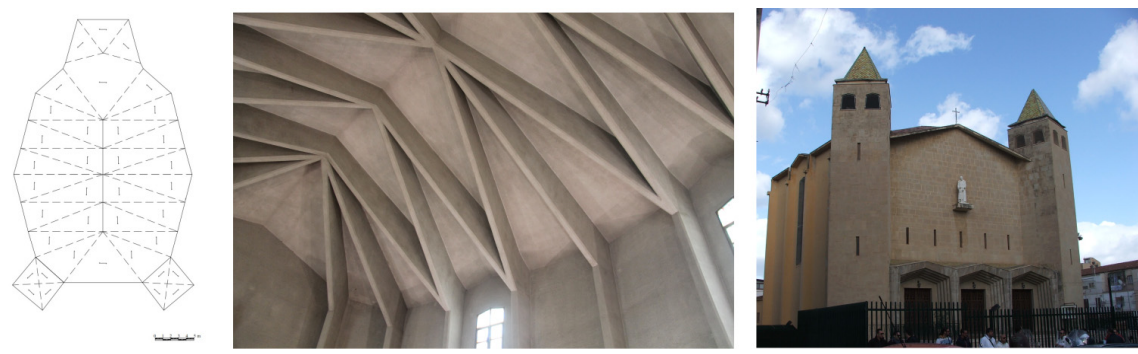

Figure 6: Palermo, church of Sant'Antonio da Padova, structural scheme, roof and façade.

The effect of this complex geometric play, symmetric in everything except for the zone of the apse, where the portals are rampant and radial, reaches full expressive maturity: the carefully worked out conformation of the roof, together with the nakedness of the reinforced concrete succeed in re-evoking the sacredness of the spaces of the Gothic cathedrals.

Furthermore, structurally, although in a period where it was not obligatory (in Italy the earthquake laws came after the Belice earthquake of 1968) the designers perfectly understood the structure's great directional vulnerability, which they tried to lessen by inserting intermediate connections between the high portals, found by means of a thermographic survey carried out during this study. Furthermore the same investigation made it possible to read the structure of the facade, otherwise illegible, since from the outside it was wholly clad with sandstone slabs.

Salvatore Caronia Roberti in 1956 chose to cover the 27 meters of span of the church of Santa Lucia with seven portals of variable cross section, in parallel, connected with beams arranged shed-wise in the longitudinal direction, but with uprights that were to a good part built in. The reinforced concrete structure is totally set forth, as is denoted by the decision to leave fair-face also the rafters of the roofs secondary framing. The presence of a suspended false ceiling to cover more than one-third of the central zone nonetheless leaves the building's structural scheme perfectly susceptible of being divined. 

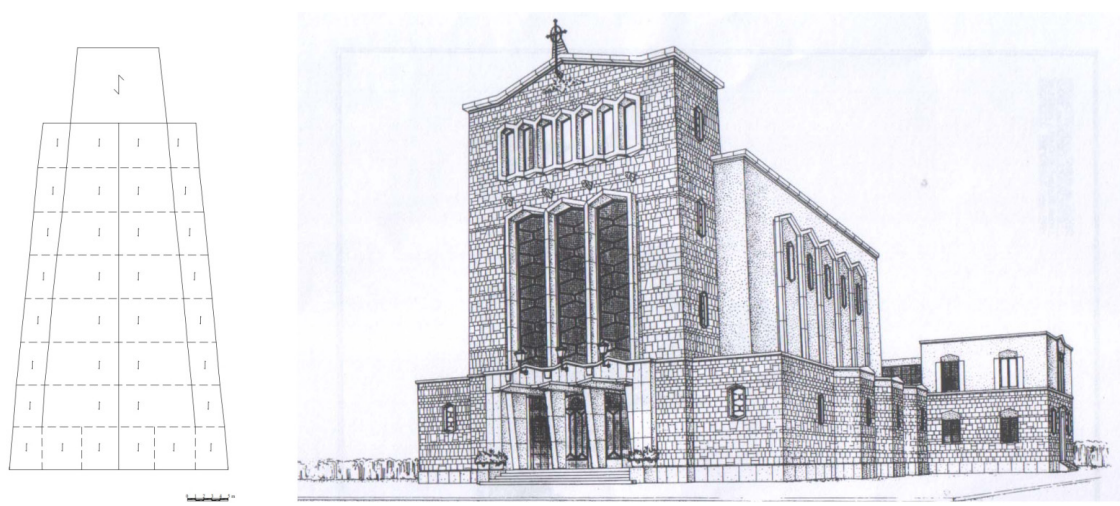

Figure 7: Palermo, church of Santa Lucia, structural scheme and perspective view.

Pietro Ajroldi's choice in the church of Santa Luisa di Merillac (1958-1961) appears singular, that is, to couple the reinforced concrete, announced on the façade (which is scanned into regular fields by the fair-face structure and segmented by slit-window openings) and in the ten shed-type portals having a tapered section both in the uprights and in the crosspieces, with the wood cladding the floor-structure fields.

The architect, whose design was heavily done over to favor a language decidedly different in the outside facade, although quite sensitive to themes of the modern movement, was not new to the mixing of the principal stylistic elements with languages and materials decidedly taken from tradition.

The wood cladding of the soffit of the floor structures, whose laying in place follows a carefully worked-out design for contrast, brings out the beams of the powerful portals.
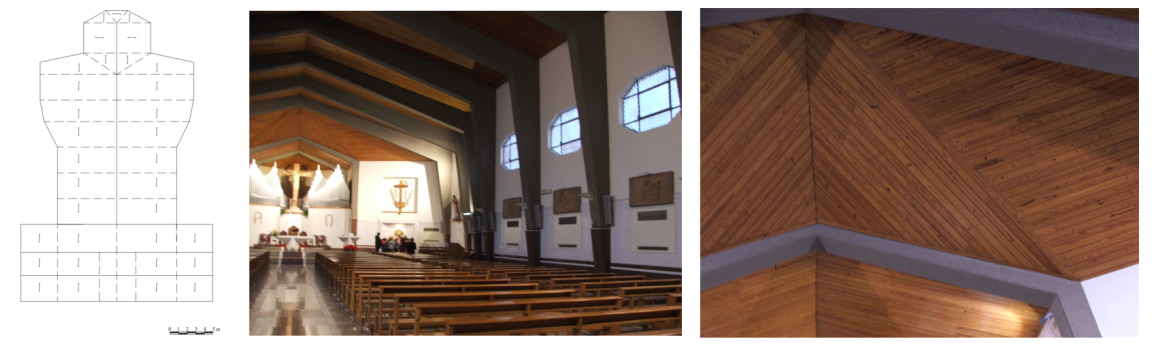

Figure 8: Palermo, church of Santa Luisa di Merillac, structural scheme, interior view and roof.

The church of San Paolo Apostolo was designed in 1959 by engineer Giovanni Ruffini (structural design by Antonio Emanuele Rizzo), who a few years later would express his maturing in the church of Sant' Ernesto, where the 
vault of the roof on reinforced-concrete ribbed bands brings to mind the wellknown designs of Pier Luigi Nervi. In the church of San Paolo Apostolo the 26 meters of clear span, not counting the side chapels, is covered by a two-pitch roof on a structure composed of eight parallel portals with variable-section traverses and uprights having the considerable height of almost 20 meters, "doubled" in two parallel pilasters connected together at regular intervals, on the interior of which is located the windowing.

The typical portals structure is therefore in this case differently worked out owing to the presence of the "saw horses" having a dual pillaring, which in fact determine the internal division of the church into nave and two aisles; these trusses are stiffened horizontally by beams in correspondence with the line of vertical windows that light the hall and conclude above with trapezoidal-section beams that sustain the roof structure. The columns, jutting out from the exterior of the facade, are connected by oblique plugs in a sort of re-proposing of the shed roofs but applied in innovatory fashion in the perimetral walls.

Outside, the church is characterized by a dissimulation of the interior plan in the full façade and by its remarking along the side prospects.
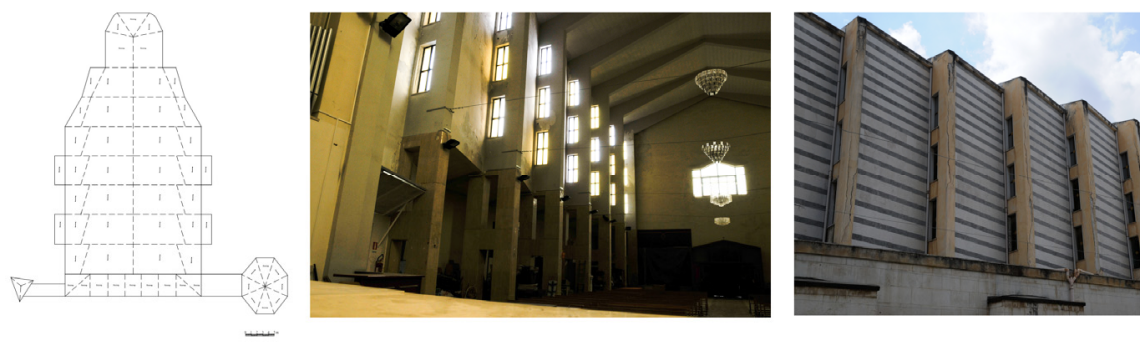

Figure 9: Palermo, church of San Paolo Apostolo, structural scheme, interior and exterior view.

Certainly greater is the degree of figurative experiment in the façade of the church of San Francesco di Sales, designed in 1963 by architect Marcello Terrasi. Here the "closure" and the "vertical perimetral walls", this being the classification of the technological system, fuse in a single whole: the eight portals that lead to the zone of the apse along the trapezoidal nave (no aisles, and having a maximum span of $24 \mathrm{~m}$ ) display, in fact, the uprights strongly inclined and doubled so as to converge in the connection of the cross-pieces, shedwise, forming pointed triangles protected by decorated glazings. The feeling of lightness granted by the vertical thrust is proposed again in the acute and splayed gable of the façade. Thus, the theme of the triangle becomes dominant for the entire building, starting from the splayed capanna and with a glazed rose window some 18 meters in diameter, continuing in the "doubling" of the columns of the internal portals. 

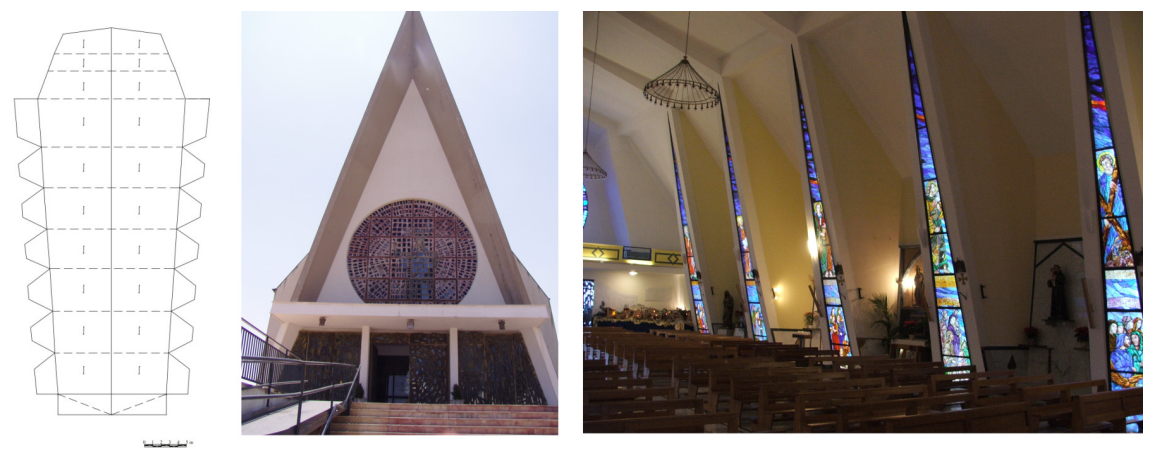

Figure 10: Palermo, church of San Francesco di Sales, structural scheme, façade and interior view.

This study brings out the characteristics common to some church typologies in a period in which reinforced concrete raises its structural and expressive potentials, finding application in the design of the churches that, owing to the use of new materials, derive from them a renewed spirit, one capable in some cases of evoking the divine quite as much as the historical religious constructions made of masonry. It appears obvious, even if as regards differences of merit, that in a study of this nature it makes no sense at all to bring out, the search for a new language that, together with the attachment to local construction traditions, well represent the moment of passage between the masonry technique and that of the reinforced concrete. A demonstration of this is, besides the juxtaposition of traditional techniques and materials with others more innovative, the different treatment of the facades and of the roofs, where a group of worthy designers and structural engineers are experimenting with solutions that are in places innovatory, to the point of becoming a crucial passage in the history of construction.

\section{Conclusions}

This short examination of the cases set forth, made within the framework of Europe's cultural climate in general and Sicily's in particular, brings out the slow and gradual process of acceptance of the new reinforced-concrete technology in the religious building from the structural, calculation and architectural standpoints. The churches built in Palermo from the two decades 1945-1965 in particular display a recurring portals scheme, whose use can be traced back, in the writer's opinion, to a particular period of the history of construction. The portals in fact represent an intermediate step between the traditional wood truss, whose form they often take up and the subsequent, more daring, solutions that use reinforced concrete in more aware fashion. 


\section{References}

[1] Montanari, G. Tra Sacro e Moderno. La committenza della Chiesa nel periodo delle avanguardie in L'architettura nelle città italiane del XX secolo: dagli anni Venti agli anni Ottanta, edit. by V. Franchetti Pardo, Jaca Book, Milan, pp. 418-424, 2003.

[2] Piacentini, M. \& Calandra, E., Concorsi e progetti di chiese da erigersi nel territorio della diocesi di Messina, in "Architettura", numero speciale, XI, 1932; Aurea, P. Il concorso per la Chiesa di Messina. Arte Razionale, in "Arte Cristiana", XXI, 2, pp. 48-52, 1933.

[3] Iori, T., Il cemento armato in Italia. Dalle origini alla seconda guerra mondiale, Edilstampa, Roma 2001.

[4] Benedetti, S. L'architettura delle chiese contemporanee. Il caso italiano, Jaca Book, Milan 2000.

[5] Mavilio, S., Guida all'architettura sacra. Roma 1945-2005, Electa, Milan 2006.

[6] Sessa, E., Le fabbriche del nuovo "sentimento" religioso nell'età contemporanea, in ID., Le chiese a Palermo, Ugo La Rosa editore, PalermoRoma 1995, pp. 64-80.

[7] Santi G., Materiali e immagine delle nuove chiese, an editorial in Costruire in Laterizio, year XXI, May-June 2008, pp. 2-3.

[8] La Chiesa oggi. Un decennio di episcopato di Sua Eminenza il cardinale Ernesto Ruffini a Palermo, 1949-1956, s.n., Palermo 1956, Stabile F.M., Palermo, la Chiesa baluardo del Card. Ruffini, in Le Chiese di Pio XII by Riccardi, A., Editore Laterza, Bari 1986; Romano A., Ernesto Ruffini. Cardinale arcivescovo di Palermo, Sciascia Editore, Caltanissetta-Roma, 2002. 